\title{
Short-term evaluation of an intra-articular technique for cranial cruciate ligament rupture in dogs using nylon or polyester
}

\section{Avaliação a curto prazo da técnica intra-articular utilizando fio de náilon ou poliéster para correção da ruptura do ligamento cruzado cranial em cães}

\author{
Tiago Carmagnani Prada ${ }^{1 *}$; Anderson Coutinho da Silva ${ }^{2}$; Bruno Watanabe Minto ${ }^{3}$
}

\begin{abstract}
Cranial cruciate ligament rupture (CCrLR) is a common condition found in the small animal routine, being correlated to traumas, obesity, genetic factors, and primary osteoarthritis (OA) in dogs. Affected animals show articular instability that, if not corrected surgically, may cause secondary OA and loss of limb function. The aim of this study was to compare short-term results of the intra-articular technique for knee stabilization after CCrLR using a surgical button associated with polyester yarn (Group A), the surgical button associated with nylon yarn (Group B), and surgical toggle associated with polyester yarn (Group C). Eighteen dogs presenting CCrLR, weight varying from 5 to $35 \mathrm{~kg}$, and different sex and breed were divided into three groups of six individuals. OA radiographic grade, pre- and post-operative lameness, surgical time, and the macroscopic aspect of cartilage were assessed. The intra-articular technique was performed by passing a suture through two tunnels, drilled in the femoral condyle and tibial crest to stabilize the knee joint. Twelve animals presented a decreased lameness and normal limb function after 15 days. On the other hand, four dogs from Group B presented complications: two dogs had suture rupture after 30 days and other two showed muscular contracture with decreased range of motion, followed by loss of limb function. In Group A, one dog showed suture rupture after 15 days and other had suture infection after 30 days. In Group C, dogs recovered normal limb function without complications. Therefore, surgical toggle associated with polyester yarn was better than the other studied materials.
\end{abstract}

Key words: CCLR. Osteoarthritis. Orthopedic. Knee joint.

\section{Resumo}

\begin{abstract}
A Ruptura do Ligamento Cruzado Cranial (RLCCr) é uma afecção comumente vista na clínica de pequenos animais e, nos cães, pode ser decorrente de traumas, obesidade, fatores genéticos e osteoartrite (OA) primária. Todos os casos apresentam instabilidade articular e quando não tratados podem evoluir para OA secundária e perda funcional do membro. O objetivo do presente trabalho foi comparar os resultados, a curto prazo, da técnica intra-articular utilizando o botão cirúrgico associado ao fio de poliéster 5 (Grupo A), botão cirúrgico associado ao fio de náilon 5 (Grupo B), e grampo cirúrgico associado ao fio de poliéster 5 (Grupo C), para a estabilização da articulação do joelho após a RLCCr.
\end{abstract}

\footnotetext{
${ }^{1}$ Discente, Curso de Doutorado do Programa de Pós-Graduação em Cirurgia Veterinária, Departamento de Clínica e Cirurgia Veterinária, Universidade Estadual Paulista, FCAV/UNESP Jaboticabal, São Paulo, SP, Brasil. E-mail: tiagocarman@hotmail. com

2 Prof., Cirurgia de Pequenos Animais, Universidade Metodista de São Paulo, UMESP, São Bernardo do Campo, SP, Brasil. E-mail: ad couto@yahoo.com.br

3 Prof., Cirurgia de Pequenos Animais, Departamento de Clínica e Cirurgia Veterinária, Universidade Estadual Paulista, FCAV / UNESP, Jaboticabal, São Paulo, SP, Brasil. E-mail: brunowminto@gmail.com

* Author for correspondence
} 
Foram utilizados 18 cães com RLCCr, com peso variando entre 5 e $35 \mathrm{~kg}$, com raça e sexo aleatórios. Os cães foram aleatoriamente divididos em três grupos de 6 indivíduos. Foram avaliados o grau de OA radiográfico, grau de claudicação pré e pós-operatório, o tempo cirúrgico e o aspecto macroscópico da cartilagem. Foi realizada a técnica cirúrgica intra-articular, utilizando-se fio para estabilização através de dois túneis cirúrgicos, um no côndilo lateral do fêmur e outro na crista da tíbia. Doze animais evoluíram de forma favorável, recuperando o apoio normal do membro após 15 dias da cirurgia. Quatro animais do grupo B apresentaram complicações sendo duas rupturas do fio após 30 dias de cirurgia e outros dois animais que apresentaram contratura muscular, com diminuição da amplitude de movimento seguida de perda funcional do membro, necessitando de novo procedimento cirúrgico. No grupo A observou-se a ruptura do fio após 15 dias da cirurgia em um animal e infecção do fio após 30 dias de pós-operatório em outro cão. Já os animais do grupo C não apresentaram nenhuma complicação pós-cirúrgica. Assim, podemos concluir que os melhores resultados foram obtidos com o fio de poliéster associado ao grampo cirúrgico.

Palavras-chave: RLCCr. Osteoartrite. Ortopedia. Articulação do joelho.

\section{Introduction}

Cranial cruciate ligament rupture (CCrLR) is one of the most common causes of pelvic limb lameness in dogs (AIKEN et al., 1992; MOORE; READ, 1996; VASSEUR et al., 1996). Dogs under this condition have a $30 \%$ chance of contralateral cranial cruciate ligament lesion (DOVERSPIKE et al., 1993; HARSEN, 1995; STAUFFER et al., 2006; VASSEUR, 1998).

Although the acute rupture of the normal cranial cruciate ligament (CCrL) can occur by trauma, in most cases the ligament is weakened due to a chronic degenerative process. Another predisposing factor to CCrLR is a poorly developed muscle mass; in contrast, excessive training for muscle gain also leads to CCrLR, which is often found in Pit Bull Terrier dogs (VASSEUR, 1998).

Most surgeons agree that surgery is the best option for CCrLR (ELKINS et al., 1991). However, no technique has been described with $100 \%$ efficiency (HULSE et al., 2011).

Surgical treatment consists of restoring the joint stability (ROOSTER, 1998), which is achieved by limiting the cranial advancement of the tibia and its internal rotation (AIKEN et al., 1992; VASSEUR et al., 1996; RACKARD, 1996). In cases of osteotomy techniques, this stability is achieved by eliminating or neutralizing cranial advancement of the tibia (SHIRAZI-ADL; MESFAR, 2007) or altering the angle of the tibial plateau (SLOCUM; DEVINE, 1983; SLOCUM; SLOCUM, 1993; WARZEE et al., 2001).

Different procedures described in the literature have shown good results, but it is worth noting that no technique produces efficient results in all sizes and breeds of dogs, and is essential that the surgeon be aware of the limitations of the applied surgical technique in order to adopt the appropriate procedures (OLIVEIRA, 2007).

The aim of this study was to compare the intraarticular technique for correcting the cruciate ligament rupture using a surgical button associated with nylon and polyester yarns and a surgical toggle associated with polyester yarn.

\section{Material and Methods}

Eighteen dogs (9 males and 9 females) with a compact skeletal configuration, weighing between 5 and $35 \mathrm{~kg}(22.72 \pm 8.29 \mathrm{~kg})$ were used.

These dogs presented CCrLR diagnosed by clinical tests of positive cranial drawer movement and tibial compression test, associated with simple stress radiography.

Exclusion criteria were the concomitant presence of patellar luxation, coxofemoral dysplasia, and autoimmune diseases as coadjuvants of RLCCr. 
Dogs were randomly divided into three groups of six animals. Group A was composed of dogs operated with the intra-articular technique using a surgical button (Figure 1a) associated with polyester $5^{4}$ (Figure 1c). Group B was composed of dogs operated with the intra-articular technique using a surgical button associated with polyamide nylon $5^{4}$ (Figure 1c). In its turn, Group C was composed of dogs submitted to the intra-articular technique with a surgical toggle (Figure $1 \mathrm{~b}$ ) associated with polyester 5 (Figure 1d).

Figure 1. Photographic and schematic images of the material used in the surgical technique. Photographic images of the surgical button (A) and toggle (B). Schematic images of the toggle with the suture yarn (C) and button with the surgical yarn (D).
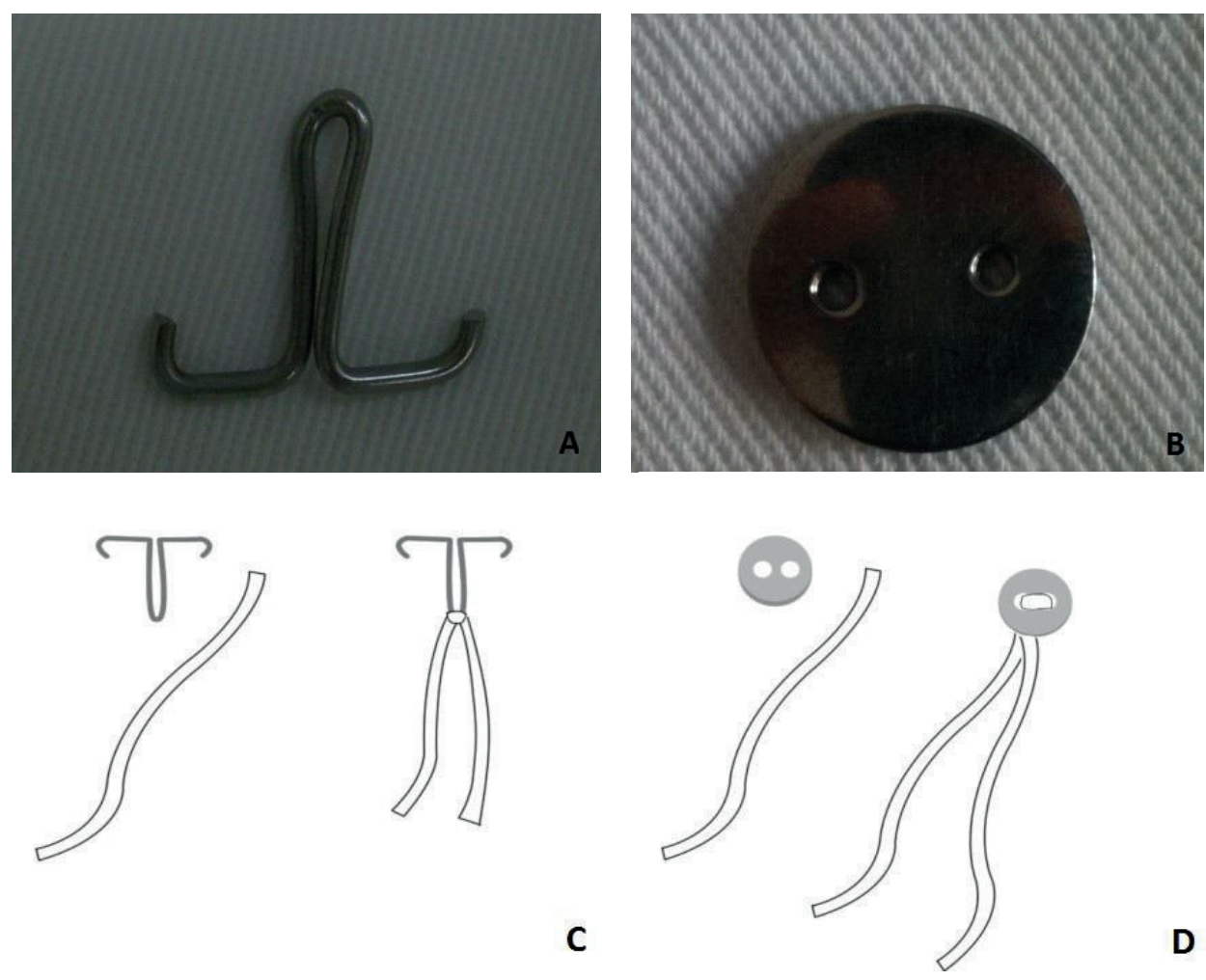

Radiographic tests were performed to determine OA grade according to the methodology described by Rendano Junior and Shoup (1998), in which five grades ( 1 to 5$)$ are defined. Grade 1 represents a joint without radiographically defined lesion whereas the other grades represent higher degrees of osteoarthritic changes.

All animals were placed in the lateral decubitus position, with the limb without lesion in contact with the table surface, and the other free for the surgery. Antisepsis was previously performed with $2 \%{ }^{6}$ chlorhexidine solution and subsequently with $0.5 \%{ }^{7}$ chlorhexidine solution. After positioning the surgical fields, an incision of approximately $8 \mathrm{~cm}$

\footnotetext{
4 Ethibond $\AA$ - Ethicon - São Paulo, SP, Brazil

Mononylon Ethilon ${ }^{\circledR}$ - Ethicon - São Paulo, SP, Brazil

Rioex 2\%® - Rioquímica - São José do Rio Preto, SP, Brazil

7 Rioex 0.5\%® - Rioquímica - São José do Rio Preto, SP, Brazil
} 
in length was performed from the cranial skin to the femorotibiopatellar joint. The access to the joint was made through a lateral parapatellar incision. With the joint exposed, the remnants of fibers of the ruptured $\mathrm{CCrL}$ were removed and the meniscus inspected. In cases of injury, the meniscus was removed. A drill was placed at the CCrL insertion point in the femur and directed to the lateral femoral condyle to perform the first surgical tunnel. Subsequently, a guide was used to pass the implant
(Figure 2) in the direction of the joint to the condyle. After that, a tunnel was made at the tibia crest after detaching the tibial cranial muscle. One band of the yarn was passed caudally to the patellar tendon and the other passed sideways to it. A band of the yarn passed through the tunnel at the tibial crest, and thus the knot was attached on the lateral side of the bone (Figure 2). Suturing of the subcutaneous tissue and skin was then routinely performed.

Figure 2. Illustrative images of the surgical technique performed. Tunnel made on the femoral lateral condyle (A); passage of the button with the tape through the tunnel in the femur (B); passage of the toggle with the tape through the tunnel in the femur (C); tunnel made on the tibia crest (D); and finished technique using the toggle (E).

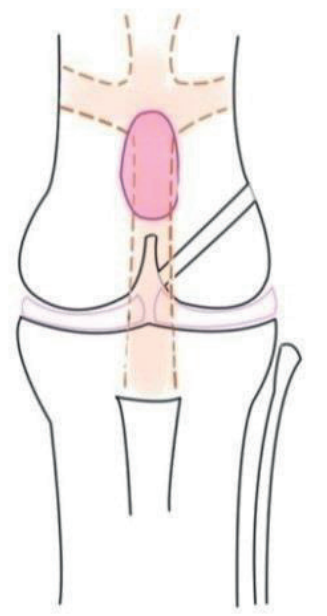

A
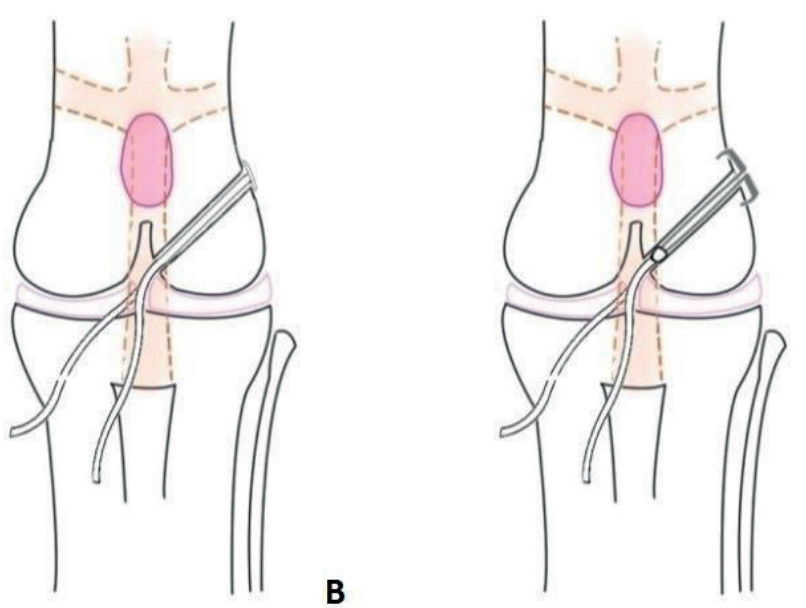

C
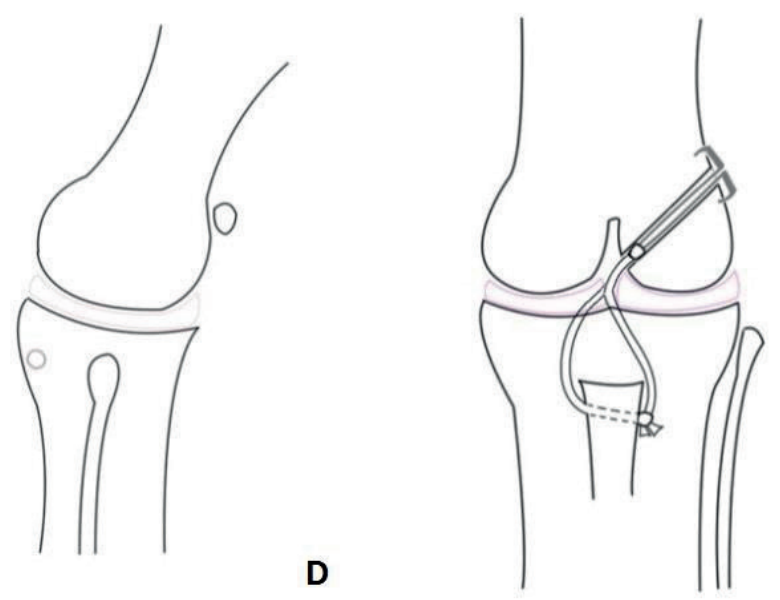

$\mathbf{E}$ 
The joint surface was assessed for all patients in the surgery after arthrotomy and classified as normal when cartilage surface was uninjured, fibrillated when cartilage surface presented irregularities and fibrillated with bone exposure when lesions deepen into the subchondral bone. Another finding included in the direct visualization was the presence of osteophytes (VELOSA et al., 1999).

All operated animals were medicated in the immediate postoperative period with Meloxicam $^{8}$ (0. $2 \mathrm{mg} / \mathrm{kg}$ intramuscularly), Enrofloxacin ${ }^{9}$ (5 $\mathrm{mg} / \mathrm{kg}$ subcutaneous), Tramadol hydrochloride ${ }^{10}$ (2 $\mathrm{mg} / \mathrm{kg}$ intravenous), and dipyrone ${ }^{11}$ (25 mg/ $\mathrm{kg}$ intramuscularly). These medications were prescribed for 5, 10, 7, and 3 days, respectively, and administered by the oral route.

Surgical time of each technique was measured from the beginning of the definitive surgical antisepsis until the last skin point was made. All intercurrences were registered in this period.

All animals were assessed on days 3, 7, 15, and 30 after surgery and graded according to the semiquantitative clinical method by Tudury and Raiser (1985), which assess the lameness degree. In this scale, grade 1 represents limb functional use and the other grades represent severity levels of changes in locomotion. These animals were assessed until medical discharge at 30 days. After this period, no assessments were performed.

Statistical analysis was established from the mean \pm standard deviation. Tukey's tests with a significance of $\mathrm{p}<0.005$ were performed for comparison between groups.

\section{Results}

All dogs were submitted to the joint stabilization procedure without the occurrence of transoperative complications. At the end of these procedures, all animals presented absence of cranial drawer movement and tibial compression test, evidencing the presence of immediate surgical stabilization.

Group A was composed of two non-defined breed (NDB) individuals, one Labrador Retriever, two American Pit Bull Terrier, and one Poodle. The average weight was $23.3 \pm 7.95 \mathrm{~kg}$ and the average lesion time was 9. $1 \pm 3.6$ days. Radiological evaluation showed a moderate degree of the joint lesion by $\mathrm{OA}$, graduated in $2.5 \pm 0.9$. The average lameness degree was 3. $5 \pm 0.6$ (Table 1), and the macroscopic articular examination showed a fibrillated articular surface $(n=2)$ and fibrillated with bone exposure $(n=4)$.

Group B was composed of six male dogs (NDB, Labrador Retriever, Rottweiler and American Pit Bull Terrier, and two Poodles). Their average weight was $21.3 \pm 9.41 \mathrm{~kg}$ with an average lesion time of $30.6 \pm 10.7$ days. Radiological evaluation showed a medium degree of severity of $3.4 \pm 0.54$ degrees. The average lameness degree was $4.1 \pm 0$. 67 (Table 1), and the joint surface was fibrillated (n $=3$ ) or fibrillated with bone exposure $(n=3)$.

Group C, on the other hand, was composed of two NDB dogs and one individual of each of the following breeds: Labrador Retriever, Rottweiler, American Pit Bull Terrier, and English Cocker Spaniel. The average weight was $23.5 \pm 4.2 \mathrm{~kg}$, being all males and with an average lesion time of $24.3 \pm 20.5$ days. Radiological evaluation showed an average degree of severity of $2.5 \pm 0.7$ degrees (Table 1). The average lameness degree was 3.8 \pm 0.8 and the joint surface was fibrillated $(\mathrm{n}=2)$, fibrillated with bone exposure $(\mathrm{n}=3)$, and normal $(\mathrm{n}=1)$.

8 Maxicam 0. 2\%® - Ourofino - Cravinhos, SP, Brazil

9 Baytril 5\%® - Bayer Vet - Belford Roxo, RJ, Brazil

${ }^{10}$ Tramadon - Cristália - Itapira, SP, Brazil

${ }^{11}$ Dipirona Ibasa 50\% - IBASA - Porto Alegre, RS, Brazil 
Table 1. Pre- and transoperative evaluation.

\begin{tabular}{|c|c|c|c|c|c|c|}
\hline \multicolumn{7}{|c|}{ Group A } \\
\hline Case & Breed & $\begin{array}{l}\text { Weight } \\
(\mathrm{kg})\end{array}$ & $\begin{array}{l}\text { Lameness } \\
\text { degree }\end{array}$ & $\begin{array}{c}\text { Lesion } \\
\text { time } \\
\text { (days) }\end{array}$ & $\begin{array}{c}\mathrm{AO} \\
\text { degree }\end{array}$ & Macroscopic evaluation of joint cartilage \\
\hline 01 & NDB & 28 & 4 & 5 & 1 & Fibrillated \\
\hline 02 & Pit Bull & 25 & 3 & 15 & 3 & Fibrillated with bone exposure \\
\hline 03 & Labrador & 30 & 3 & 12 & 3 & Fibrillated with bone exposure \\
\hline 04 & Poodle & 6 & 3 & 10 & 4 & Fibrillated with bone exposure \\
\hline 05 & NDB & 26 & 3 & 5 & 2 & Fibrillated \\
\hline 06 & Pit Bull & 25 & 5 & 8 & 3 & Fibrillated with bone exposure \\
\hline \multicolumn{7}{|c|}{ Group B } \\
\hline 01 & Pit Bill & 32 & 5 & 35 & 4 & Fibrillated with bone exposure \\
\hline 02 & Rottweiler & 35 & 5 & 25 & 3 & Fibrillated \\
\hline 03 & Poodle & 9 & 3 & 20 & 3 & Fibrillated \\
\hline 04 & Poodle & 8 & 4 & 52 & 3 & Fibrillated with bone exposure \\
\hline 05 & Labrador & 20 & 4 & 22 & 4 & Fibrillated with bone exposure \\
\hline 06 & NDB & 24 & 4 & 30 & 4 & Fibrillated \\
\hline \multicolumn{7}{|c|}{ Group C } \\
\hline 01 & Labrador & 28 & 3 & 13 & 3 & Fibrillated \\
\hline 02 & Pit Bill & 23 & 3 & 5 & 2 & Fibrillated \\
\hline 03 & Cocker & 18 & 3 & 10 & 1 & Normal \\
\hline 04 & Rottweiler & 30 & 5 & 13 & 3 & Fibrillated with bone exposure \\
\hline 05 & NDB & 20 & 5 & 45 & 3 & Fibrillated with bone exposure \\
\hline 06 & NDB & 22 & 4 & 60 & 3 & Fibrillated with bone exposure \\
\hline
\end{tabular}

No statistical difference was observed between lameness degrees considering the different groups. However, a statistical difference was observed in the lesion time and degree of osteoarthritis, which was higher in Group $2(p=0.001)$.

The animals from these three groups, in which no complications were observed in the first three postoperative days, recovered limb function during this period, presenting light support (lameness degree 3). At 7 days, animals presented support from moderate to good, representing lameness degree 2, and, in the assessment of 15 days after surgery, they presented normal support (lameness degree 1). No statistical difference was observed between groups in the postoperative assessments.
However, in Group A, animal 4 presented polyester yarn rupture at 15 days of medical progress, after a new trauma reported by its owner. Yarn rupture occurred in the surgical tunnel of the femur. Animal 1 presented licking in the surgical wound reported by its owner and an infection in the polyester yarn after 30 days, having to be reoperated. The other animals presented favorable progress until the last analysis at 30 days. In Group $\mathrm{B}$, dogs 1 and 3 presented muscular contracture after 15 days of surgery, followed by total loss of limb support. Animals 4 and 6 presented yarn rupture after 30 days of surgery, but without a history of trauma reported by their owner. The other animals presented favorable progress until the last analysis 
at 30 days. In Group C, all animals were free of postoperative complications until the last analysis at 30 days.

All animals with post-surgical complications were reoperated using an extra-articular technique to stabilize the joint.

In addition to CCrLR, $72 \%$ of the operated animals presented partial luxation of the medial meniscus, being necessary to perform a partial meniscectomy.

\section{Discussion}

Radiographically, 16 out of 18 animals with traumatic CCrLR presented some degree of OA as described by Rendano Junior and Shoup (1998). In all animals, this degree was directly related to the lesion time and lameness degree. These results are in agreement with Fujita et al. (2005), who studied radiographically 36 dogs with CCrLR.

In the animals studied here, the early osteophyte formation is particularly noticeable, especially in dogs with more time of joint involvement. In humans, this bone remodeling is usually delayed, unlike what is seen in dogs. According to Rayward et al. (2004), osteophytes appear at the edges of the trochlea after two weeks of CCrL transection. However, Biasi et al. (2001) and Dupuis and Harari (1993) reported a longer time interval (4 weeks) after CCrL lesion. Baraúna Junior et al. (2007) also observed radiographic findings of degenerative joint disease in dogs suffering traumatic CCrLR prior to the surgical procedure. The average radiographic degenerative lesion of these animals was 123 days. Several studies have shown that the instability generated by the $\mathrm{CCrL}$ lesion leads to joint degeneration with radiographic signs in 70 to $90 \%$ of the animals (SELMI et al., 2002; TATARUNAS et al., 2006). These data show that osteoarthritis induced by CCrLR is severe and rapidly evolving, unlike in humans with knee ligament lesion. CCrL reconstruction after a surgical procedure does not impede OA progression, but only prevents its rapid progression (CHAUVET et al., 1996; INNES; BARR, 1998; LAZAR et al., 2005).

Joint macroscopic examination of 17 of the 18 dogs showed changes in cartilage color and texture, as well as fibrillation and presence of osteophytes, thus confirming the radiological findings. These findings are in accordance with those of Velosa et al. (1999), who observed similar changes in 3- to 14week rabbits after partial meniscectomy. Buquera et al. (2002) performed a study analyzing nine joint surfaces of animals with CCrLR and demonstrated the erosion of the lateral joint surface of femoral condyles. In dogs with a history of older lesions, more pronounced lesions were observed, such as subchondral bone exposure, osteophytes with synovium clamping, and reduction of joint space, similar to those found by Velosa et al. (1999) after 22 weeks of partial meniscectomy in rabbits.

Moreover, a medial meniscus lesion was observed in $72 \%$ of the operated cases, which was corrected by using total medial meniscectomy. No animal presented lateral meniscus lesion. According to Vasseur et al. (1996), medial meniscus lesions are frequently found in cases of CCrLR. Such lesion occurs due to femoral condyle movement in the rigidly fixed medial meniscus. Some studies have reported up to $70 \%$ of medial meniscus lesion (GAMBARDELLA et al., 1981; RALPHS; WHITNEY, 2002). Tatarunas et al. (2006) obtained a result of $40 \%$ for medial meniscus lesion and $5 \%$ for lateral meniscus lesion after arthroscopic visualization.

Surgical procedure time was measured in minutes and resulted in $48^{\prime} \pm 4.3$ for Group A, 46 \pm 3. 2 for Group B, and $48^{\prime} \pm 5.4$ for Group C, which demonstrates quickness in the performance of the surgical technique. Carrillo et al. (2003) used an intra-articular technique to repair $\mathrm{CCrL}$ and resulted in an average of 70.4 minutes for performing the 
procedure. Muller et al. (2009), performing another type of intra-articular technique, had an average of 55 minutes of surgical time.

Lameness degree in the preoperative was classified according to the modified Tudury and Raiser (1985) method and ranged from 3 to 5. These results point to the direct relationship between the lesion degree and the lesion time and the OA degree. Animals with a longer lesion time presented a higher lameness degree and respective OA degree. Baraúna Júnior et al. (2007) observed a similar occurrence when quantified the preoperative lameness degree; they obtained an average value of 3. 6 using the same method. Tatarunas et al. (2006) used a graduation method similar to the one used in our experiment and obtained similar values in the preoperative assessment. Tamburro et al. (2012), using an extra-articular technique, obtained satisfactory results from one month postoperative, with an average of two months for the normal limb function after the surgical procedure.

At the first postoperative evaluation, after 3 days, all animals with a favorable progress presented a degree of light support, regardless their group, corresponding to grades 3 and 4 . In the second evaluation, at 7 days, animals presented a moderate support of the limb, being classified in grades 3 and 2. These results are in agreement with Muller et al. (2009), who obtained similar results with an intraarticular technique.

In the third postoperative evaluation, after 15 days, the animals with favorable progress returned to the normal limb function, regardless their group. This result corroborates the finding of Carrillo et al. (2003), surpassing the average expectation for limb function return after extra-articular surgeries, which is of four months (AIKEN et al., 1992; MOORE; READ, 1996). In contrast, in more recent studies of extra-articular techniques, after one month of performing the surgical procedure, animals presented a close to normal support, and, after 2 to 3 months, they presented normal limb support
(HULSE et al., 2011; TAMBURRO et al., 2012).

All operated animals were absent from immobilization in the postoperative period since the graft used was a synthetic material. However, in cases of natural grafts, complications occur during the remodeling phase, in which the graft may deform or loosen, and thus the use of external immobilization is recommended (GAGLIARDO et al., 2008).

In Group A, one animal presented a yarn rupture after 10 days of progress. After the surgical reintervention, the rupture point of the implant was in the tunnel made in the femur. This fact may have occurred due to implant friction with the beginning of the surgical tunnel of the femur. Vasseur et al. (1996) and Camargo et al. (2001) also reported similar complication. Another point even more common for implant rupture is the intercondylar fossa with osteophytes or stenosis (SMITH, 2000). In addition, one animal presented an infection of the surgical wound proven after bacterial culture. This complication probably occurred due to surgical wound licking by the animal, which led to a secondary contamination and subsequent reaction to the polyester yarn. In fact, the polyester yarn is a multifilament yarn and has a greater predisposition to contamination (SMITH, 2000). However, Selmi et al. (2002) tested this yarn for LCCrR correction and obtained no cases of reaction to such material.

In Group B, two animals presented femoral quadriceps muscle contracture ten days after the surgical procedure, leading to total loss of limb support. These animals underwent a new surgical procedure, where the nylon implants were found to be intact but shorter than their total length. No reports can be found in the literature about such phenomena with nylon yarn. However, Dulisch (1981) found excessive edema with or without the presence of a fistula associated with a subsequent bacterial yarn contamination. Sicard et al. (2002) stated the advantage of nylon yarn as having a low infection rate, in addition to presenting a low cost, 
being easy to find and sterilize, and being available in different diameters.

\section{Conclusions}

Considering the experimental conditions adopted in this study, the surgical technique of intra-articular stabilization proved effective for stabilizing the knee joint. In addition, the most suitable material for performing this technique is the polyester yarn associated with surgical toggle.

\section{References}

AIKEN, S. W.; BAUER, M. S.; TOOMBS, J. P. Extraarticular fascial strip repair of the cranial cruciate deficient stifle: technique and results in seven dogs. Veterinary and Comparative Orthopedics and Traumatology, West Lafayette, v. 5, n. 4, p. 145-150, 1992.

BARAÚNA JÚNIOR, D.; ROEHSIG, C.; ROCHA, L. B.; CHIORATTO, R.; TUDURY, E. A. Técnica de interligação extra capsular fêmoro-fabelo-tibial na ruptura do ligamento cruzado cranial em cães: achados clínicos e radiográficos. Ciência Rural, Santa Maria, v. 37, n. 3, p. 769-776, 2007.

BIASI, F.; RAHAL, S. C.; LOPES, R. S.; VOPI, R. S.; BERGAMO, F. M. N. Alterações no líquido sinovial do joelho de cães com osteoartrite induzida pelo modelo de Pond e Nuki. Arquivo Brasileiro de Medicina Veterinária e Zootecnia, Belo Horizonte, v. 53, n. 5, p. 34-48, 2001.

BUQUERA, L. E. C.; CANOLA, J. C.; PADILHA, J. G.; FURLANI, J. M.; TALIERI, I. C.; SELMI, A. L. Radiografia e macroscopia após estabilização extraarticular utilizando fascia lata, fio de poliéster trançado ou fio de poliamida para correção da ruptura do ligamento cruzado cranial em cães. Ciência Rural, Santa Maria, v. 32, n. 1, p. 73-78, 2002.

CAMARGO, O. P. A.; SEVERINO, N. R.; AIHARA, T. Resultado a médio prazo da reconstrução da lesão crônica do ligamento cruzado anterior com prótese de poliéster. Revista Brasileira de Ortopedia, São Paulo, v. 36, n. 4, p. 111-116, 2001.

CARRILLO, J. M.; SOPENA, J. J.; RUBIO, M. Técnica de horquilla modificando su anclaje distal. Consulta de Difusión Veterinaria, Castellón, v. 11, n. 103, p. 69-74, 2003.
CHAUVET, A. E.; JOHNSON, A. L.; PIJANOWSKI, G. J.; HOMCO, L.; SMITH, R. D. Evaluation of fibular head transposition, lateral fabellar suture, and conservative treatment of cranial cruciate ligament rupture in large dogs: a retrospective study. Journal of the American Animal Hospital Association, Lakewood, v. 32, n. 3, p. 247-255, 1996.

DOVERSPIKE, M.; VASSEUR, P. B.; HARB, M. F. Contra-lateral cranial cruciate ligament rupture: incidence in 114 dogs. Journal of the American Animal Hospital Association, Lakewood, v. 29, n. 10, p. 167170, 1993.

DULISCH, M. L. Suture reaction following extraarticular stifle stabilization in dog. Part II. A prospective study of 66 stifles. Journal of the American Animal Hospital Association, Lakewood, v. 17, p. 572-574, 1981.

DUPUIS, J.; HARARI, J. Cruciate ligament and meniscal injuries in dogs. Compendium on Continuing Education for the Practicing Veterinarian, Yardley, v. 15, n. 2, p. 215-228, 1993.

ELKINS, A.; PECHMAN, R.; KEARNEY, M. T. Retrospective study evaluating the degree of degenerative joint desease in stifle joint of dogs following surgical anterior cruciate ligament rupture. Journal of the American Hospital Association, Lakewood, v. 27, p. 533540, 1991.

FUJITA, Y.; HARA, Y.; YAMAGUCHI, S.; SCHULZ, K. D.; TAGAWA, M. Direct and indirect markers of cartilage metabolism in synovial fluid obtained from dogs with hip dysplasia and correlation with clinical and radiographic variables. American Journal of Veterinary Research, Washington, v. 66, n. 12, p. 2028-2033, 2005.

GAGLIARDO, K. M.; SPIRONELLI, D. B.; EIMANTAS, G. C. Métodos de tratamento para a ruptura completa do ligamento cruzado cranial em cães - revisão. Arquivo da Apadec, Maringá, v. 8, n. 2, p. 667-672, 2008.

GAMBARDELLA, P. C.; WALLACE, L. J.; CASSIDY, F. Lateral suture technique for management of anterior cruciate ligament rupture in dogs: a retrospective study. Journal of the American Animal Hospital Association, v. 17, p. 33-38, 1981.

HARSEN, G. L. G. A retrospective study of 165 cases of rupture of cranial cruciate ligament. Canadian Veterinary Journal, Lakewood, v. 36, n. 4, p. 250-251, 1995.

HULSE, D.; SAUNDERS, B.; BEALE, B.; KOWALESKI, M. Extra-articular stabilization of cranial cruciate deficient stifle with anchor systems. Tierarztl Prax Ausg K Kleintiere Heimtiere, Bethesda, v. 39, n. 5, n. 5, p. 363-367, 2011. 
INNES, J. F.; BARR, A. R. S. Clinical natural history of postsurgical cruciate deficient canine stifle joint: year 1 . Journal of Small Animal Practice, Ontario, v. 39, n. 7, p. 323-332, 1998.

LAZAR, T. P.; CLIFFORD, R. B.; JACEK, J. D.; JEFFREY, N. P.; CORREA, M. Long-term radiographic comparison of tibial plateau leveling osteotomy versus extracapsular stabilization for cranial cruciate ligament rupture in the dog. Veterinary Surgery, Germantown, v. 34, n. 2, p. 133-141, 2005.

MOORE, K. W.; READ, R. A. Rupture of the cranial cruciate ligament in dogs. Part I. The Compendium on Continuing Education for the Veterinarian, Yardley, v. 18, n. 3, p. 223-234, 1996.

MUller, D. C. M.; PIPPI, N. L.; BASSO, P. C.; SCHOSSLER, J. E. W.; ROSA, M. B.; SERAFINI, G. M. C. Emprego do implante sintético - malha de polipropileno - para promover a estabilização articular, após desmotomia dos ligamentos cruzados em cães proposição técnica. Ciência Rural, Santa Maria, v. 50, n. 2, p. 89-96, 2009.

OLIVEIRA, D. A. M. Lesão do ligamento cruzado cranial em cães (Canis familiaris): revisão de literatura. 2007. Monografia (Trabalho de Conclusão de Curso de Especialização em Cirurgia de Pequenos Animais) - Centro de Ciências da Saúde, Curso de Medicina Veterinária, Universidade Castelo Branco, Rio de Janeiro.

RACKARD, S. Cranial cruciate ligament rupture in dogs. Irish Veterinary Journal, Londres, v. 49, p. 481484, 1996.

RALPHS, S. C.; WHITNEY, W. O. Arthroscopic evaluation of menisc in dogs with cranial cruciate ligament injuries: 100 cases (1999-2000). Journal of the American Animal Hospital Association, Lakewood, v. 221, n. 11, p. 1601-1614, 2002.

RAYWARD, R. M.; THOMSON, D. G.; DAVIES, J. V.; INNES, J. F.; WITHELOCK, R. G. Progression of osteoarthrtitis following TPLO surgery: a prospective radiographic study of 40 dogs. Journal of Small Animal Practice, Ontario, v. 45, n. 2, p. 92-97, 2004.

RENDANO JUNIOR, V. T.; SHOUP, C. L. Radiological diagnosis of canine osteoarthritis. In: Management of canine osteoarthritis. Proceedings of A PFIZER SYMPOSIUM HELD IN CONJUCTION WITH CONGRESS W. S. AN. VET. AS, 23., 1998, Buenos Aires. Proceedings... Buenos Aires: Rocca, 1998. p. 2730 .
ROOSTER, H.; RYSSEN, B. V.; BREE, H. V. Diagnosis of cranial cruciate ligament injury in dogs by tibial compression radiography. The Veterinary Record, London, v. 142, n. 14, p. 366-368, 1998.

SELMI, A. L.; PADILHA, J. G. F.; BARBUDO, G. R.; BUQUERA, L. E. C.; CANOLA, J. C. Clínica e radiografia da prótese de poliéster em cães com ruptura do ligamento cruzado cranial. Ciência Rural, Santa Maria, v. 32, n. 2, p. 793-798, 2002.

SHIRAZI-ADL, A.; MESFAR, W. Effect of tibial tubercle elevation on biomechanics of the entire knee joint under muscle loads. Clinical Biomechanics, Oxford, v. 22, n. 1, p. 344-351, 2007.

SICARD, G. K.; HAYASHI, K.; MANLEY, P. A evaluation of 5 types of fishing material, 2 sterelization methods, and a crimp-clamp system for extra-articular stabilization of the canine stifle joint. Veterinary Surgery, Germantown, v. 31, n. 1, p. 78-84, 2002.

SLOCUM, B.; DEVINE, T. Cranial tibial thrust: A primary force in the canine stifle. Journal of the American Veterinary Medicine Association, Lakewood, v. 183, n. 4, p. 456-459, 1983.

SLOCUM, B.; SLOCUM, T. D. Tibial plateau leveling osteotomy for rapair cranial cruciate ligament rupture in canine. Veterinary Clinics of North America: Small Animal Practice, Oxford, v. 23, n. 4, p. 777-795, 1993.

SMITH, B. Viewpoints in surgery cruciate ligament rupture extracapsular stabilization. Australian Veterinary Journal, Melbourne Victoria, v. 78, n. 6, p. 382-383, 2000.

STAUFFER, K. D.; TUTTlE, T. A.; ELKINS, A. D. Complications associated with 696 tibial plateau leveling osteotomies (2001-2003). Journal of the American Hospital Association, Lakewood, v. 42, n. 1, p. 44-50, 2006.

TAMBURRO, R.; PINNA, S.; TRIBUIANI, A. M.; PANACEA, A.; CARLI, F.; VENTURINI, A. Biceps femoris muscle transposition for treatment of cranial cruciate ligament rupture in small breed dogs. Journal of Veterinary Science, Seoul, v. 13, n. 1, p. 93-98, 2012.

TATARUNAS, A. C.; MATERA, J. M.; IMAGAWA, V.; MASTROCINQUE, S. Arthroscopic study of the dog's knee joint with clinical cranial cruciate ligament injury. Brazilian Journal of Veterinary Research and Animal Science, São Paulo, v. 43, p. 129-136, 2006. Suplemento. 
TUDURY, E. A.; RAISER, A. G. Redução de fraturas distais de fêmur de cães, empregando dois pinos de Steinmann em substituição aos de Rush. Revista Centro de Ciências Rurais, Santa Maria, v. 173, n. 2, p. 1817$1865,1985$.

VASSEUR, P. B. Articulação do joelho. In: SLATTER D. Manual de cirurgia de pequenos animais. 2. ed. São Paulo: Manole Ltda., 1998. p. 2149-2201.

VASSEUR, P. B.; GRIFFEY, S.; MASSAT, B. J. Evaluation of the Leeds-Keio synthetic replacement for the cranial cruciate ligament in dogs, an experimental study. Veterinary and Comparative Orthopedics and Traumatology, Stuttgart, v. 9, n. 2, p. 29-37, 1996.
VELOSA, A. P. P.; OLIVEIRA, A. M.; CARRASCO, S.; CAPELOZZI, V. L.; TEODORO, W. R.; YOSHINARI, N. H. Meniscectomia parcial como modelo experimental de osteoartrite em coelhos e efeito protetor do difosfato de cloroquina. Revista Brasileira de Reumatologia, São Paulo, v. 47, n. 6, p. 401-410, 1999.

WARZEE, C. C.; DEJARDIN, L. M.; ARNOCZKY, S. P.; PERRY, R. L. Effect of tibial plateau leveling on cranial and caudal tibial thrusts in canine cranial cruciate deficient stifles: an in vivo experimental study. Veterinary Surgery, Germantown, v. 30, n. 3, p. 278-286, 2001. 
